\title{
織 機
}

津田駒工業(株)

長谷川憲司

\section{1.はじめに}

原始時代から始まった糸を紡ぎ布を作ってゆく技 術は，寒さや外敵から身を保護する目的から身を飾 る用途へと, 時代の要求に沿って変遷してきた. と りわけ近年の科学技術の発達は, 絨維加工技術の面 においても飛躍的発展をむたらした。織機について いえば, 新しい素材の出現, 製品用途の多樣化, 品 質の高級化, 生産の高効率化は次々と新しい機械を 生み出し, ここ数十年, 非常な勢いで発達してきた. ここでは, ヨーロッパで 4 年ごとに開かれている ITMA（国際繊維機械見本市）および日本で 4 年ご とに開かれている OTEMAS（大阪国際繊維機械シ ヨー）等の出展機から織機の変革発展をみつつ, ま た, 津田駒工業の開発対応も付記した。

\section{2. 有杼から無杼へ}

織機の近代化は, 従来の有杼織機の改善と各種無 杼織機の開発の 2 つの方向で進められてきた. 有杼 織機では, まずは高速化の追求, 次いでラージパッ ケージ化が進められ，1960年（昭和35年）頃には高 速化での合理化機運と労働力不足に伴う自動化要求 が強まる中, 200 rpm 以上の高速機が出現, また, ボ ビンローダーや，ルームワインダー方式によるョコ 系供給装置が開発され, 自動化, 省力化が図られた。 さらに, 生産性向上の 1 つの手段として広幅化が行 われた時期でああった. 一方, 無杼織機は, 有杼織 機に比べ機構構造や部品の損耗, エネルギー効率で 高速化に適しており, シャットル運動による騒音を 気にせずとす良い等の点で, 急速に開発が進められ
始めたのあこの頃である.

無杼織機の研究は古くから行われていた. その存 在が認められるようになったのは，1950年代の後半 である.まずは, グリッパー織機で, 次いでレピア, ウォータージェット織機である. 1963年 (昭和38年) ITMA ハノーバー, 1967年 (昭和42年) ITMA バー ゼルで実用機としての展示がなされたが，製織範囲 に限界があり，開発にはまだまだ資金と時間が必要 といったところで，有杼織機を追放するまでには至 らない段階であった。しかし，前述したように有杼 織機での限界を感じていた織機メ一カーは無杼織機 の開発の手を緩めず，その改良開発に努力し，今日 の無杼織機移行への原点となったのである.

エアジェット織機は，1975年（昭和50年）ITMA ミラノでようやく実用機としてその性能が認められ るようになった. 先行 3 機種に比べ, スタートは出 遅れたあのの, 技術進歩には著しいあのがあった. これが他の無杼織機の性能向上の刺激剤となり, 無 杼化へ之明確に決定づける役割を果たした．以後， 有杼織機の ITMA 出展は縮小し, 消隇へと繫がっ たのである. あちろん織布業界の合理化追求, 生産 性向上の強いニーズに基づいていることはいうまで あない.

近年, マイクロコンピュータの開発とともにその 採用, 高性能なセンサー, アクチュエーターの開発 とそれらの制御技術の向上など，いわゆるエレクト ロニクス化が, 製織範囲の拡大, 操作性の向上等, 織機の性能向上に大きく寄与した. 特にジェット織 機のよこ入れ方式が高速化に適しているという特長 と相まって,これらの織機への取り込みが急速に進 
み, 現在のハイテクジェット織機となっているので ある。

図 1 に織機の生産性向上, 図 2 に ITMA 出展機 の織機台数推移, 図 3 に ITMA 出展機の回転数推 移, 図 4 に ITMA 出展機のよこ入れ率の推移, 図 5 に無杼織機の機種を示す。

現在, 世界には約 350 万台の織機が設置されてい る. そのうち, $85 \%$ が依然有杼織機であるといわれ ている.この有杼織機すべてが無杼織機に替わると はいわないまでも, 生産性の上ではジェット織機の 相手ではない。また，レピア織機, グリッパー織機

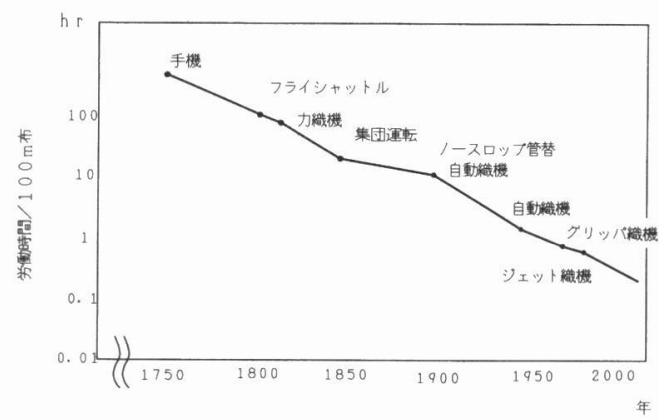

図 1 織機の生産性向上

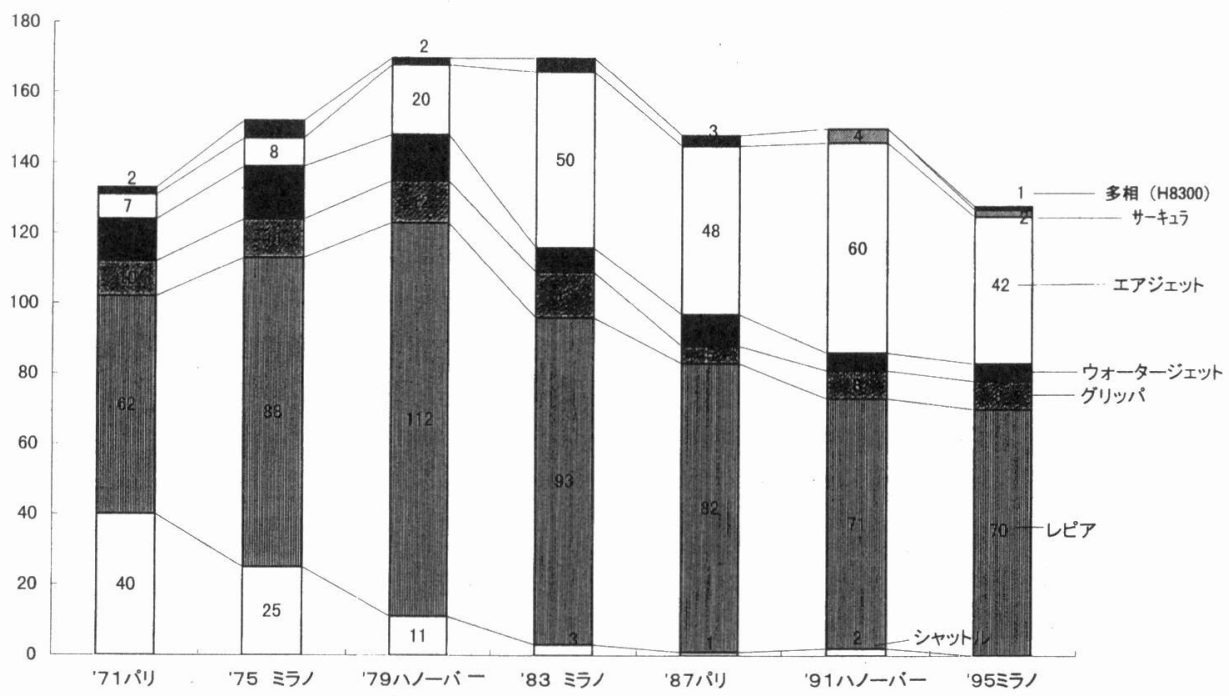

図2 ITMA 織機出展台数の推移

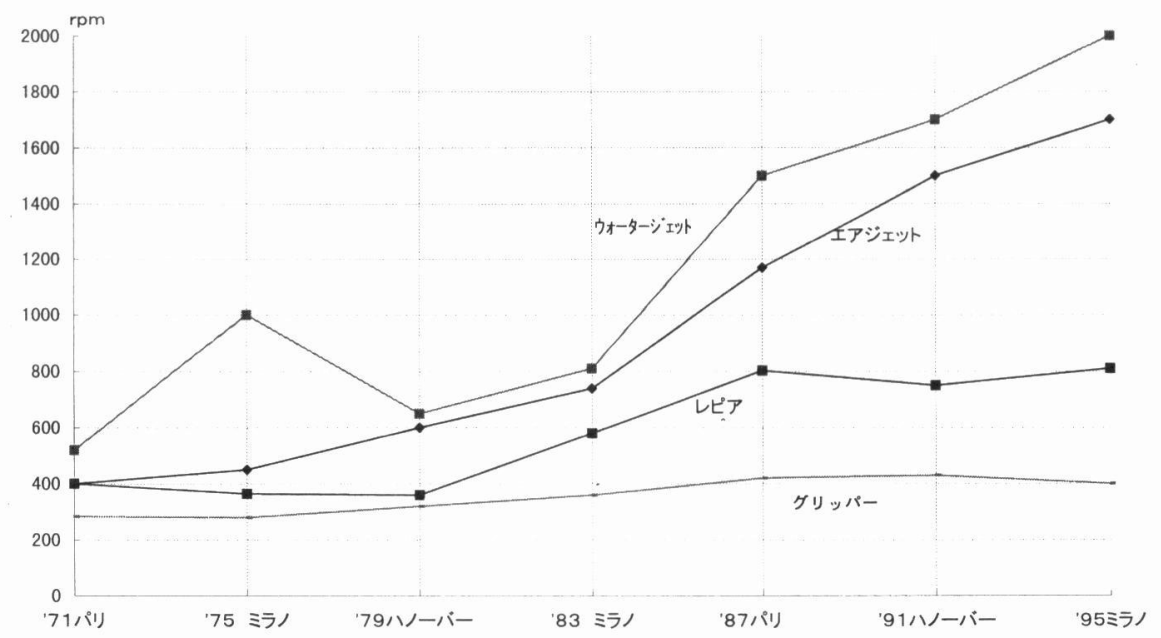

図 3 ITMA 出展機回転数の推移 


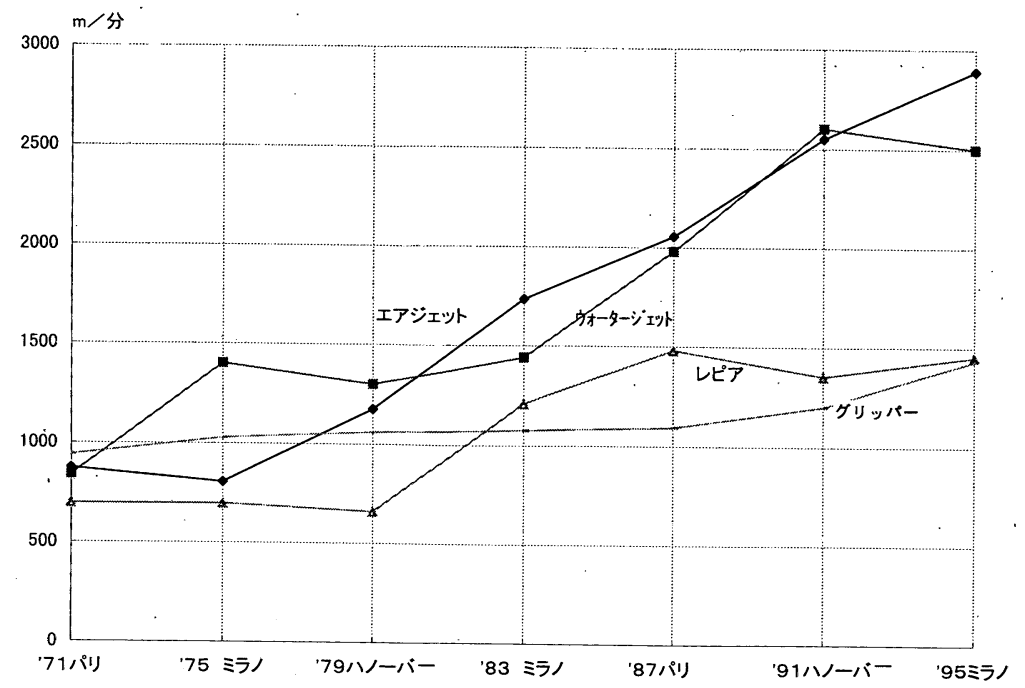

図 4 ITMA 出展機のよこ入率の推移

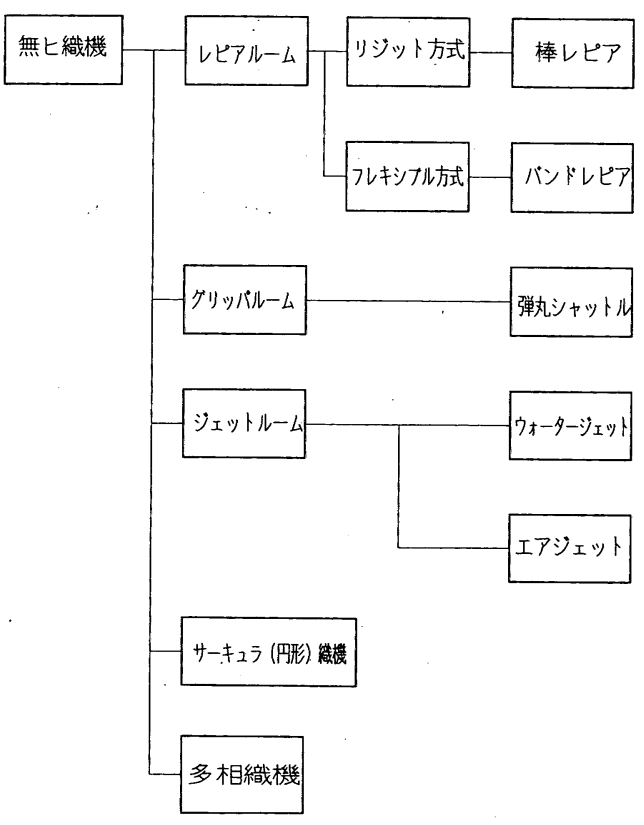

図 5 無七織機の分類

においてあ高速化が進んでおりこれと汎用性とが相 まって，ますます無杼化へと移行することになろう (図6).

\section{3.レピア織機}

シャットルの高速飛走に伴う振動, 騒音, また機 械的安定性の問題解決が技術的に難しいということ から，1925年 (昭和元年) の GABLER (フレキシブ

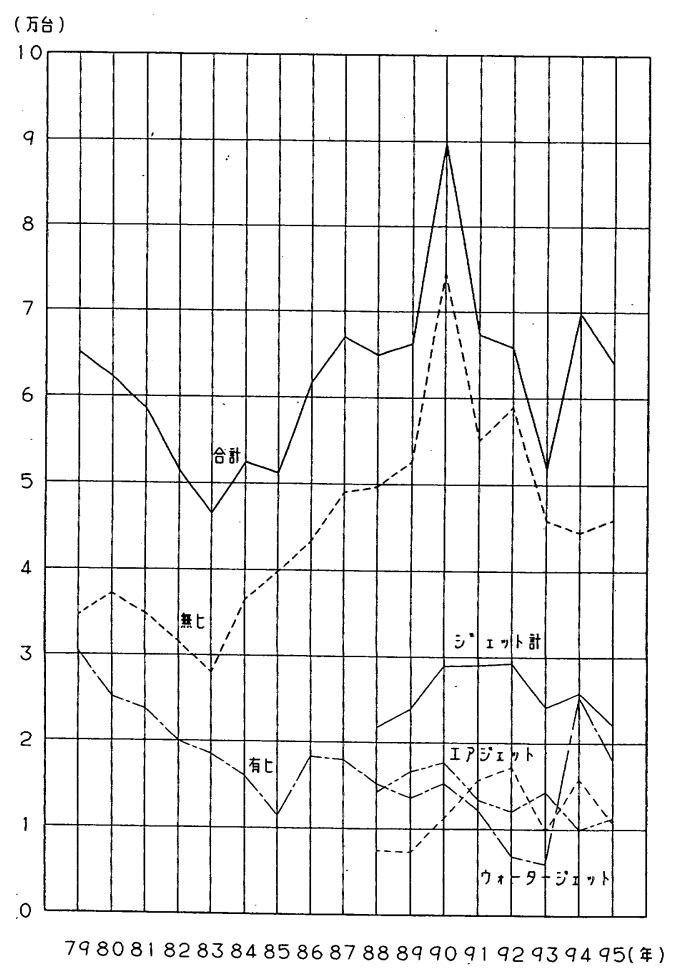

困 6 世界の織機据付台数の推移 (ITMF)

ル方式）および1935年（昭和10年）の DEWAS（リ ジット方式）考案のよこ入れ原理を応用する織機と して1945年 (昭和20年)にレピア織機が開発された. 1959 年（昭和 34 年）ITMA パリで DRAPER 社 （USA）がフレキシブル方式で実用機を発表, それ 
を引き金として各社レピア織機の開発が加速されは じめた. 3 年後の 1962 年 (昭和37年) ATME (米国国 際繊維機械展) で, SACM 社 (フランス) がリジッ 卜方式を出展した。ここで注目された点は, DRAPER 社のよこ入れ方式はしごき式であり， SACM 社は把持式であったことである.この 2 方 式が以後のよこ入れの基本となった，その後レピア 織機の汎用性之高生産性が認められ，1963年（昭和 38年) ITMA ハノーバーでは10社がレピア織機13台 を出展, 急テンポで開発が進んでいった.

我が国におけるレピア織機の製造は海外メ一カー との技術提携により始められた。 それは前記1963年 ITMA が引き金となった。

1965年 石川製作所 一DRAPER 社 DSL 型 1966年 津田駒工業 一 SACM 社 MAV 型 1969年 平岩鉄工所 -DESVEUS 社 1972年 岩間織機製作所-LENTZ 社 1976年 豊和工業—-SAURER DIEDERICH 社 当社が SACM 社と技術提携したのは，1）フィラ メント織物が製織できること，2）多色が可能なこ と，3）織物品質が有杼織機並みであること，4）保 全調整が容易であること，が大きな理由であった。 MAV 型は1968年（昭和 43 年）に生産を開始し, $\mathrm{TAV}$ 型と形式を変更した後も含めて1990年 (平成 2 年）に廃止するまで, 11,000 台を生産した。

レピア織機の汎用性拡大とともに, ドビーやジャ カード織物分野への普及も活発になり, 1971年（昭 和46年) ITMA パリではレピア織機の出展台数がシ ヤットル織機を上回ることになった。 また, この展 示会での特色は, 織物の多様化に対応して棒レピア から穴明けテープレピアに，よこ入れはしごき式か ら把持式へと方向づけがなされたことである. 1975 年 (昭和50年) ITMA ミラノではシャットル織機と レピア織機の出展比率が $1: 2$ となり, レピア織機 の全盛期に入る. しかし, 同時にRUTI 社 (スイス) より高速のエアジェット織機が出展され, その高生 産性に先導された形でレピア織機も高速追求へと開 発が進むのである。1979年 (昭和54年) ITMA 八) ーバーでは，高分子材料等を用いてレピア往復運動 部の質量軽減を行い，慣性力を小さくして高速運転 （350rpm）を実現させた。ユニークなものとしては 2 面取りでの生産性の拡大, 据付面積の縮小を狙っ た SAURER500型 2 面レピア織機の出現である.

さて, ヨーロッパメーカーの高速レピア織機に対 抗するために, 国内メーカ一各社も1980年（昭和55
年) 頃から本格的に高速機の開発に取り組んでい る.

ジェット織機との共存の中でレピア織機は, 織機 にとって最も重要な汎用性の拡大のためにレピアへ ッドの性能向上と, より一層の高速化のためにバン ドおよびレピアヘッドの軽量化に努力した。 一方, 周辺機器の電子化とともに, 織機本体むサーボモー ターを利用した電動化が一般化された。 また，よこ 入れに対しては自動口合わせ装置（APF）の採用に より, レピア織機での操作性の向上と織物品質の向 上に大きく寄与している. 1990年（平成 2 年）に入 り,レピア織機にあマイクロコンピュータが搭載さ れ, データ, タイミングなどがデジタル化された。

このことは工場内での保全だけでなく, 工場運営面 でむ管理を容易にさせた. このように国内のレピア 織機むめざましく性能がアップしている.

一方でジェット織機も，より一層の汎用性拡大に 努力しており, 従来のレピア織機分野の織物も製織 可能になりつつある.このような状況下でのレピア 織機の生きる道は, 小ロット, 多品種, 短納期に対 応し，また原糸メーカーが開発に力を入れている新 素材を容易に織りこなせる織機の開発, 改良であろ う.

\section{4.ウォータージェット織機}

有杼織機のよこ糸搬送手段をシャットルに依存し ている限り, 飛躍した回転数の向上は図れない。レ ピア, グリッパー織機の出現である程度の目的は達 せられてきたものの，なお不十分であった。これら を超える手段として考えられたのが流体の利用で, 空気であり, 水であった. ウォータージェット織機 はSVATY（チェコ）により発明されたあのである. 発明の動機はェアジェットでの織幅限界, すなわ ち, 搬送力不足をウォータージェットによって解决 しょうとしたものである. ELITEX 社（チェコ）に よって実用化，1955年 (昭和30年) ITMA ブリュッ セルにKOVO 社ブランドで出展された. 日本では, 1961年（昭和36年）には東京国際見本市で初公開さ れ注目を集めた。

我が国においてあ独自開発を進めていた日産自動 車（旧プリンス自動車工業）が LW10型ウォーター ジェット織機を完成させたのもこの時期といわれて いる. 1965年（昭和40年）末までにリングノズル, スプリング内装式プランジャーポンプ, 通電フィー ラーなどウォータージェットの基本が出来上がり, 
その基本のほとんどが今日まで引き継がれている. 親水性の糸には全く不適合で, 疎水性の系のみとい う汎用性面でのハンディーを背負っての出発であっ たが, ナイロンなどの疎水繊維が適しているとのこ とで，北陸を中心とする合緎フィラメント織物産地 の生産者にとっては画期的な織機として受け入れら れていった．ただ，この時期の織機は夕フ夕専用機 的性格のあのであったことはいうまでもない. 1967 年 (昭和 42 年) ITMA バーゼルに開口装置としてカ ム機を搭載出展, 以後高速ドビー機の開発， 1 越替 え， 2 越替えの開発など，汎用性が急速に高められ た. 1975年 (昭和50年) ITMA ミラノでは，4色自由 交換, 広幅 $280 \mathrm{~cm}, 1,000 \mathrm{rpm}$ 高速機を出展, ウォ一 タージェット織機の汎用性, 高生産性を見せつけ た.

一方，遠州製作は1961年（昭和36年）の東京国際 見本市後に KOVO 社ウォータージェット織機のラ イセンスによる国産化に踏み切り，1965年（昭和40 年）から販売を開始した。当初は KOVO 社オリジ ナルウォータージェット織機の製作であったが, 徐々に改良を加え, 同社独自のウォータージェット 織機に変えていった。しかし，1977年（昭和52年） に研究開発と生産販売を中止, 1978年 (昭和53年), METEOR 社（イタリア）にその製造販売権を譲渡 し撤退した。

さて当社といえば1974年（昭和49年）にウォー夕 ージェット織機の開発を再開, 1976年 (昭和51年) の第 1 回 OTEMAS で ZW 100型として初出展, 翌 年から販売を開始した。 KOVO 社の日本展示から 15年後となる. ZW 100型の基本構成は在来型のウォ ータージェット織機と同じであるが，よこ系測長眝 留に独自開発の回転ドラム, ブロー把持方式の連続 測長方式（RDP，図 7）を採用し，注目を集めた。 RDP はよこ系を緊迫させずに整然と貯留でき，ビ リの出やすい強撚系の製織性は抜群であり，1 越替 え, 2 越替え装置の開発は, 折からのジョーゼット ブームによって, シャットル織機からウォータージ エット織機への転換を加速させた。 こうしてウォー タージェット織機は次の天然糸ライク, 新合繊の時 代の高生産機として不動の機種に成長する.

一方, 円高, 繊維不況での夕フ夕等の定番品のコ スト競争力をつける上で, 高速化む精力的に進めら れた。 当社の開発ステップから見れば，1980年（昭 和55年) ZW200型，1984年 (昭和59年) ZW300型と なり, 1995年 (平成 7 年) の ITMA ミラノでは ZW

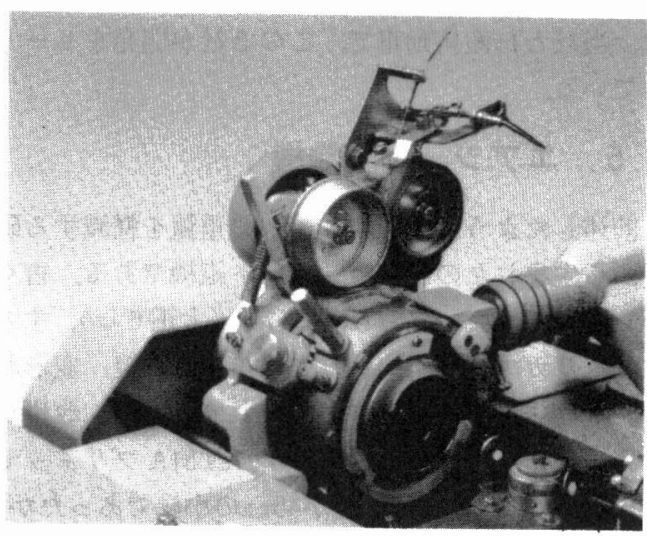

図 7 RDP 回転ドラム貯留（津田駒）

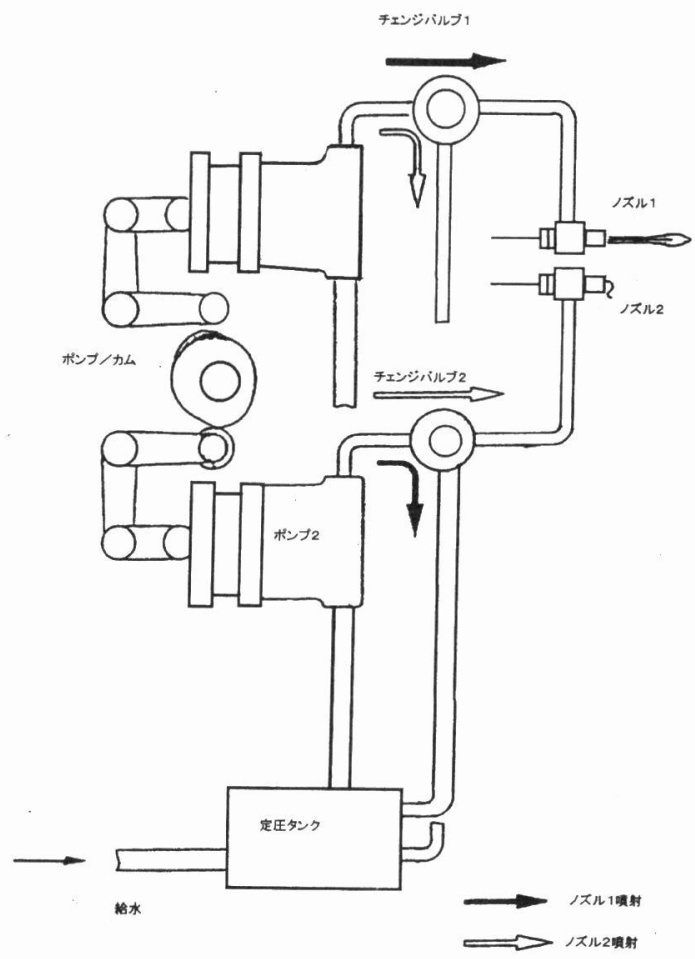

図 8 ッインポンプシステム（津田駒）

400 型で $2000 \mathrm{rpm}$ を実演, 工場生産機として 1000 rpm の現実性を示した。

最近のウォータージェット織機は, 合繊織物のコ ストパフォーマンスと生産性の優位さを背景に, レ ピア織機の領域である300デニール以上の太番手強 撚糸織物や, 目付 600 グラムを超える極厚地織物, ツ インポンプシステム（図 8) によるよこ系の異種, 異 番手組み合わせなどで汎用性拡大も着実に進んでい る.

現在, ウォータージェット織機の代表メーカー 
は, 当社と日産自動車で, この 2 社が開発をリード している.

\section{5.エアジェット織機}

前述したように, シャットルの重量を軽減する研 究から生まれたのがェアジェット織機である. 古く から研究が始まっており，1917年 (大正 6 年), すで にアメリカで特許が出されている，その後，変形お さ, 補助ノズル等の特許む出されて, 工夫, 改良が 加えられた。1955年（昭和30年）ITMA ブリュッセ ルに KOVO 社（チェコ）が45cmの小幅であったが, $700 \mathrm{rpm}$ のエアジェット織機を出展した。 その後 MAXBO 社（スウェーデン）が1958年（昭和33年） のマンチェスター緘維機械展に $90 \mathrm{~cm}$ 幅を出展し, エ アジェット織機が注目されるようになった。

日本では1960年（昭和35年），大阪国際見本市に MAXBO 社と技術提携した村田機械がエアジェッ 卜織機を出展し, エアジェット織機が広く知られる ようになった．当時のエアジェット織機は織幅や織 物が限られており，また，よこ入れも不安定で品質 あ悪く，実用には程遠いものであった，その後， 1975年（昭和50年）ITMA ミラノに RUTI 社（スイ ス）が TE. STRAKE 社（オランダ）と共同開発し た「変形おさとマルチノズル」を用いたェアジェッ 卜織機を出展し, 従来の織機に比べて優れた性能を 示した.これが日本の織機メーカーに強い危機感を 与え，我が国におけるエアジェット織機の開発を早 めることとなる．こうした中で1976年（昭和51年） OTEMASに当社がェアジェット織機 ZA 100型 2 台を出展, エアジェット織機への高い関心を集め た. 次いで1977年 (昭和52年) に日産自動車も開発, 公開した. 当社は,「変形おさとマルチノズル」方式 のよこ入れシステム, 日産は「エアガイドとシング ルノズル」方式であった。この 2 つのよこ入れ方式 はいろいろの観点から比較評価を受けながら成長し てゆくことになる.1979年（昭和54年）のITMA 八 ノーバーには豊田自動織機製作所が「エアガイドと マルチノズル」という併用方式のエアジェト織機を 初出展し, 日本の競合メーカーが出揃うことになっ た. 当時, 変形おさ方式のエアジェット織機に対す る織布業界の目はかなり厳しいものがあり，それを 克服する開発努力が今日の「変形おさとマルチノズ ル」方式への一本化となった（1991年（平成 3 年） ITMA でエアガイド方式は姿を消す)，例えば，変 形おさの精度, 品質の向上, 補助ノズルの性能向上,
使用エア量の低減,ひいては製作コストの低減など である.

1983年（昭和58年）ITMA ミラノではエアジェッ 卜織機の高生産性を鮮明にした。 各社が高速機, 広 幅機の出展と競いあったのである. また，この展示 会でのもう 1 つの特色は, マイクロコンピュータを 採用し，それまでメカニカルに行っていた調整や制 御が, 電気的設定器によって行われるメカト口織機 の登場である. 電磁バルブによるよこ入れ制御（図 9)，サーボモーターによりたて糸の送りを制御する 電動送出 (図10), 電動モーター利用のドラム式貯留 装置（図11）などである．これを契機に各織機メ一 カーのマイクロコンピュータ採用, エレクトロニク スの取り込みが加速された. 1985年（昭和60年） OTEMAS, ATME では各装置の機能は大きく改善 され, 調整作業時間の短縮, 操作性の向上など, い ままで機械的方法では難しいとされていたものが一 挙に解決したことになる．同時に自動化という面む 大幅に進歩した，当社が初めてよこ入れ不良系の自

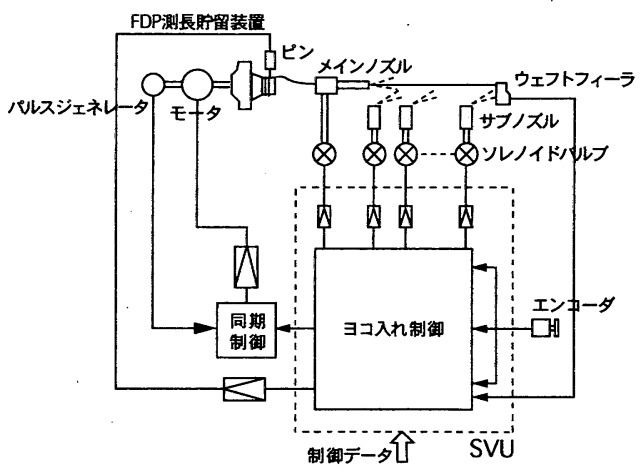

図 9 よこ入れ制御（津田駒）

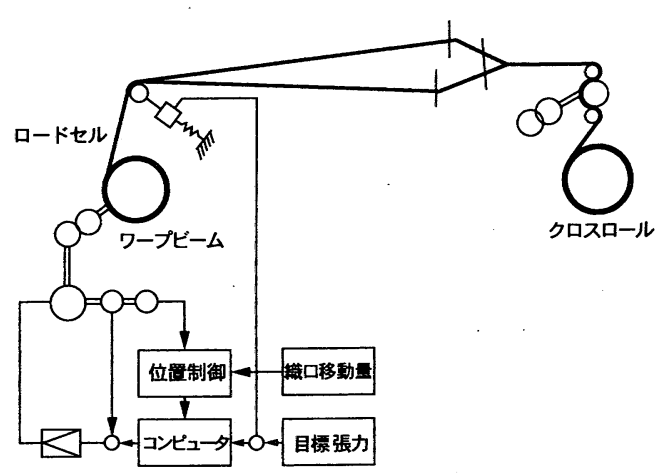

図10 電動送出（津田駒） 


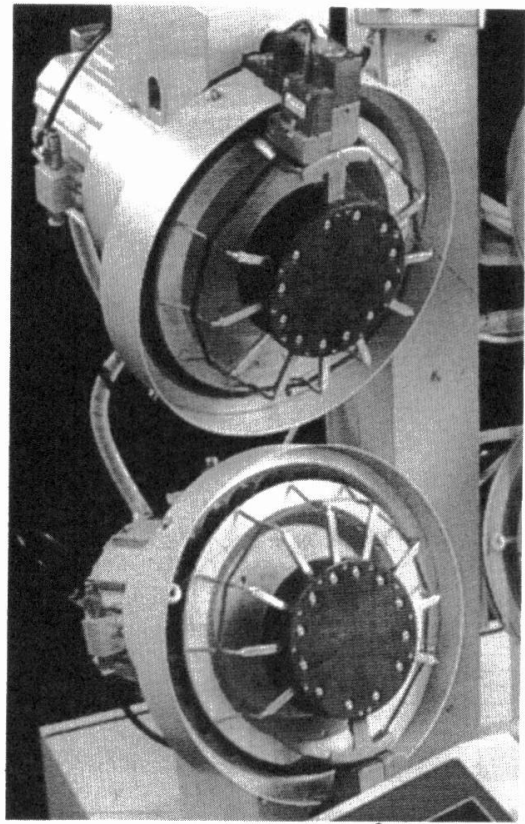

図11 電動ドラム貯留（津田駒）

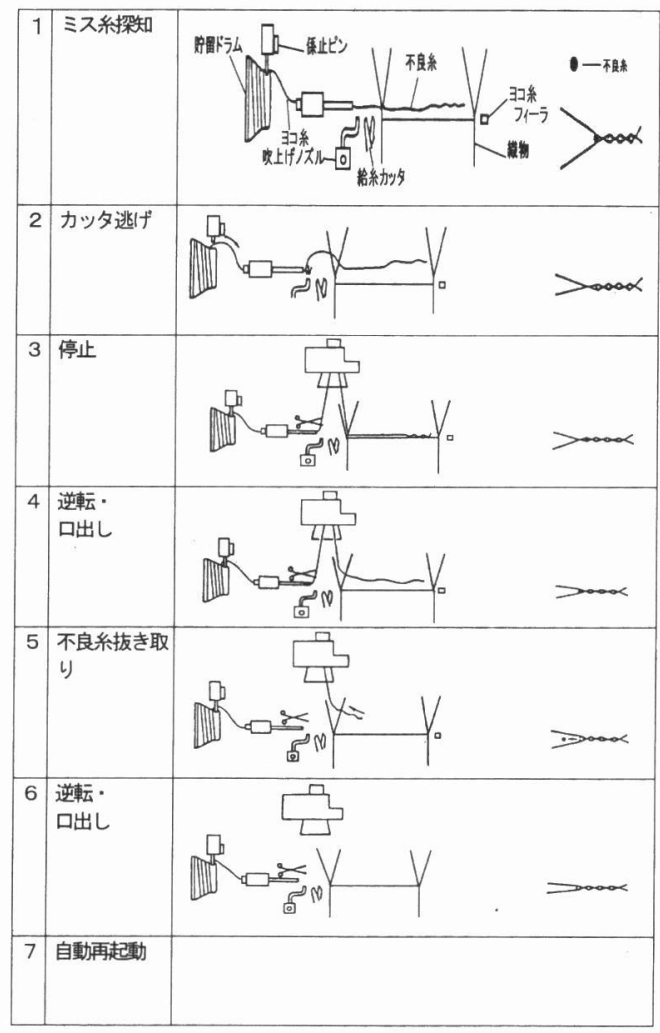

図12 APR 自動よこ糸補修装置（津田駒）

動補修装置（図12）を開発, 公開したのもこのとき である. その後もマイクロコンピュータ応用の進展
はめざましく, 現在では多数の高性能のマイクロコ ンピュータが搭載され，インテリジェント織機とい っても過言ではない.

マイクロコンピュータ採用を始めとする織機のエ レクトロニクス化は日本の織機メーカーが常にリー ダーシップをとってきた．日本のエレクトロニクス 産業が世界のトップレベルにあったことが, 織機メ 一カーのエレクトロニクス化技術を後押ししたので ある．逆にグリッパー織機のような超精密織機が日 本では育たなかったこともその反証であろう.

1987年（昭和62年）ITMA パリでは, 1000rpm 以 上という, より高速化に拍車がかかり, 同時に汎用 性の拡大としてょこ入れ 6 色織機 (当社, 他) が出 現した. また, よこ入れ不良系の自動補修装置は早 くあ各メーカーが装着し一般化した。また，コンピ ユータ支援による織機群, 織布工程, 工場管理シス テムの提案もなされ, 現在の CIM 構築へと受け継 がれている.

国内でも先発 3 社の当社, 日産, 豊田に追随すべ く相次いでェアジェット織機を発表した時期でもあ る. 1985年 (昭和60年) の OTEMAS で豊和工業が, 1988年（昭和63年）ATME で石川製作所が 1989年 (平成元年) OTEMASには岩間織機および平岩鉄 工所が出展, 国内メーカーは 7 社となり, ますます 競争が激化することになる。

1991年 (平成 3 年) ITMA ハノーバーになると, エアジェット織機は成熟期に入った観を呈した。ま た, 日本メーカーの優位性を決定づけた展示会でむ ある. マイクロコンピュータを駆使し, 高速化はも とより, よこ入れの自動制御の高度化により, 可能 なよこ系範囲が拡大されレピア領域に入り込むまで に汎用性が拡大された。これからはェアジェット織 機の時代である，というインパクトを与えた。 さら にここでェアジェット織機に大きな変化がある。前 述のように，エアガイド方式のよこ入れが消滅し， 変形おさ方式に一本化されたことである. エアガィ ド方式では高生産性と汎用性に限界を生じたためで ある。

自動化，省人化む大きく取り上げられた．布の切 り下ろしの自動化とその搬送 (図13), 上こ系の搬送 と給系スタンドへの供給, ドラム〜ノズル間の系通 し，そして，オートスタートと一連のよこ系補給の フルオート化を狙ったよこ糸パッケージ自動供給シ ステム (図14) である. 前者は今日, 織布工場の FA 化を進める上での重要アイテムとなっているが, 後 


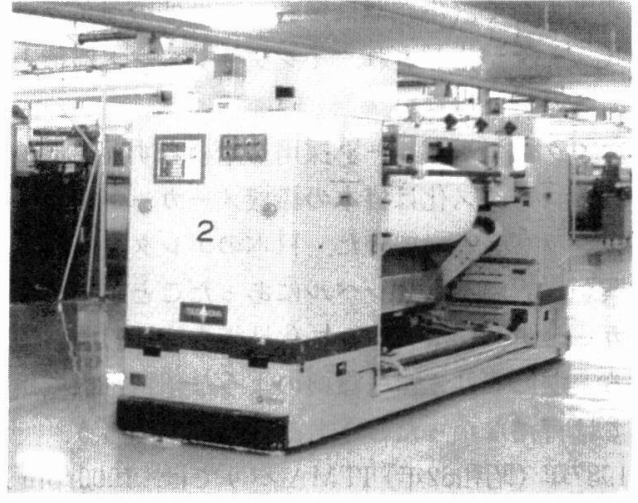

図13 クロスドッフィングシステム（津田駒）

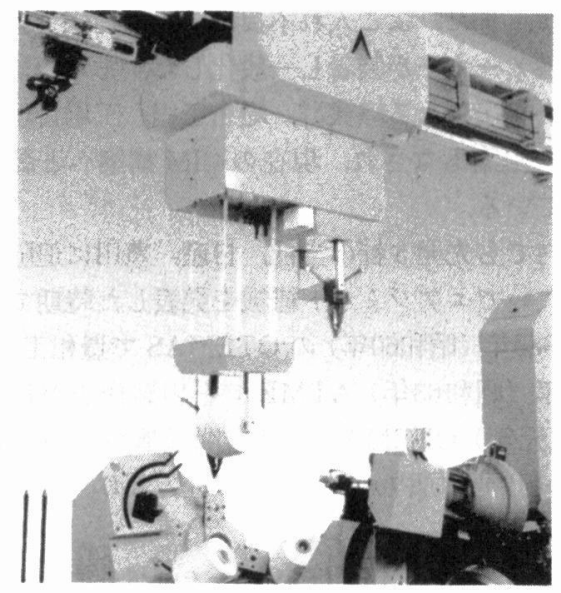

図14 パッケージサプライシステム（津田駒）

者は装置のコストの面から実用化に至っていない，

1993年 (平成 5 年) OTEMAS では, 日本勢の工 アジェット織機とヨーロッパ勢のレピア織機という 競合パターンが明確になった。エアジェット織機の 高速化, 汎用化の一層の進展とともに, レピア織機 あ高速化の時代に入るのである。他方，織布業界の 生産方式の多様化から多品種, 小ロット生産之 $\mathrm{QR}$ に対するアプローチが始まった。「クイックスタイ ルチェンジ（QSC)」（図15）いわゆる品種替えの迅 速化，合理化である，たて糸の準備から運搬，仕掛 け, 運転, 品質の確保まで, いかに短時間で少ない 人間にて行うかである。運搬車の工夫，仕掛け装置 の工夫, 織機本体の改良などトータルとして織機メ 一カーの提案を行った。このショーで, 当社は新し い開口装置を出展した。 1 枚 1 枚の枠を個別のサー ボモーターを使って駆動制御する電子開口装置（図 16) である，開口パターン, 曲線等のあらゆるファ

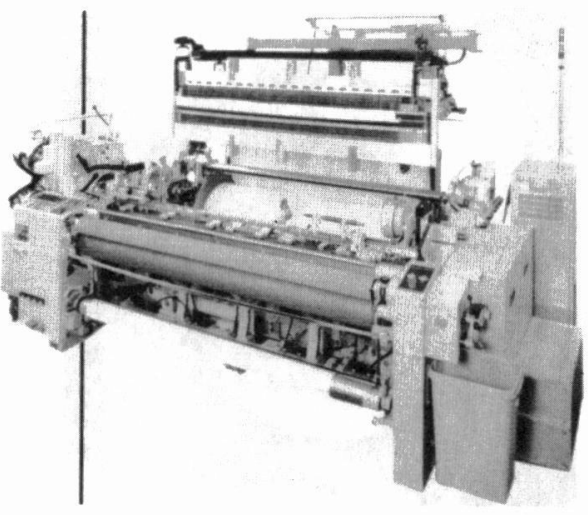

図15 クイックスタイルチェンジシステム（津田駒）

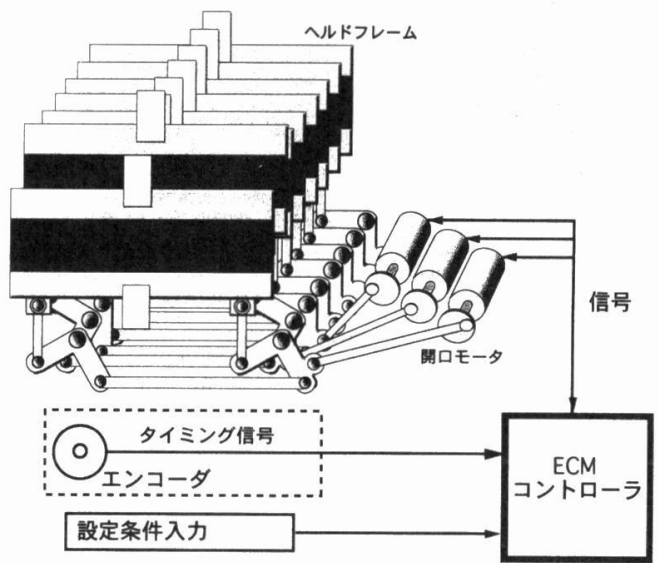

図16ＥCM 電子開口（津田駒）

クターが電子的入力で自由に設定できる画期的な開 口装置で，QSC とのコンビネーションによってそ の優秀さに注目が集まった。

\section{ITMA95 での新しい織機の出現}

いままでは個々の織機について書いてきたが, 1995年 (平成 7 年) ITMA ミラノからは織機全体か ら見た視点でまとめることにする.

このITMA の特長として, 日本勢のエアジェッ ト織機, ヨーロッパ勢のレピア織機という図式は変 わっていないが, 今まで精力的に進めてきた高速 化, 自動化の大幅な進展がストップし, 汎用性, 多 様性を強調する開発姿勢へとメーカーの変化が表れ た。高速化ではエアジェット織機で1700rpm，ウォ ータージェット織機で $2000 \mathrm{rpm}$ （いずれも当社）と 過去最高のものであるが，全体としてみれば横這い であり，回転数アップによる生産性上昇は鈍化傾向 になった (図17)，高速であっても稼働安定指向にな 


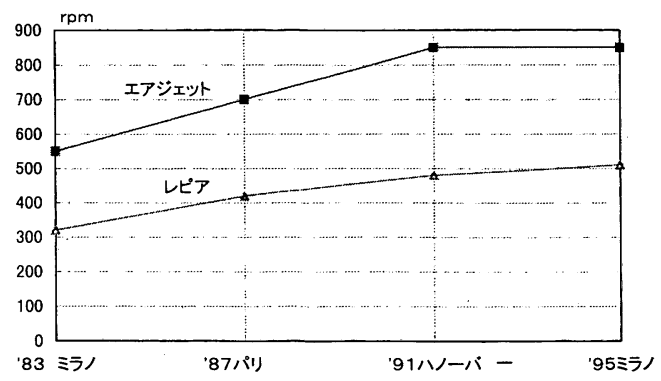

図17 ITMA 出展織機の平均回転数の推移

ったとみるべきである. 反面，各機種とあ広幅化に よる生産性向上は進んでいる。 また，汎用性につい てはエアジェット織機ではフィラメント強撚糸か ら，毛織物，デニム，夕オルなどスパン一般織物に 加え, 多彩で難しい織物へ, 装置的には 6 色, 8 色へ の多色化，ドビー，ジャカード織りなどの多様化を 図っており,レピア織機は複合系を始め金銀糸, 絹, 意匠糸などェアジェット織機を意識した多岐な織物 展開となっていることである.

$\mathrm{QR}$ としての QSC あ時代のニーズから各メ一カ 一とも積極的に取り組んでいる，QSC 自体の性能 向上はもう 1 つであったが, 形態として従来のドロ ーイング時点からの新パターンを準備する方法に対 して，新しく種バ夕を専用置台にてタイイング準備 して行う方法が提案され，各織布工場に合った選択 肢が増えた。

FA 化としての自動化装置の出展も減少し，開発 は一段落した．設備コストがかかり，ユーザーには 受け入れがたいという実態すあろう。表 1 に，1991 年 (平成 3 年) ITMA と 1995 年 (平成 7 年) ITMA のエアジェット織機の出展比較を示す.

特記すべきは新しい2つの織機の展示である. 1 つは開発が中断されていた多相開口織機である.

SULZER・RUTI社がポストエアジェット織機を 狙って開発した多相ェアジェット織機 M8300（図 18）である。1979年（昭和 54 年）ITMA に BENTLEY 社が出展した ORBIT のエアジェット化であ る. マルチリニア開口でたて糸方向に形成された 4 つの杼口に 4 本の主ノズルから順次よこ入れし，変 形おさと補助ノズル（通常のエアジェット織機と同 じ）によってよこ系を搬送し，打ち込んでゆく．よ こ入れ率は, $5414 \mathrm{~m} /$ 分 $(190 \mathrm{~cm}$ 幅で 2850 picks / 分) という超高生産性の織機である. 開口, おさ打構造 の特殊性から織物は限定されると思うが, 高生産性 はむとより低騒音，低振動には注目すべき織機の出
表 1 ITMA'91. '95 に於けるエアジェット織機の出展 比較

\begin{tabular}{|c|c|c|c|c|c|c|c|}
\hline & ITMA年次 & 91 & 95 & & & \multirow[b]{2}{*}{91} & \multirow[b]{2}{*}{95} \\
\hline & 総台数 & 60 & 43 & & & & \\
\hline & $\sim 170$ & 6 & 1 & & 自動ヨコ系補修（片側） & 44 & 31 \\
\hline オ & $\sim 190$ & 38 & 25 & 自 & 11 (両側) & 2 & 2 \\
\hline サ & $\sim 230$ & 1 & 4 & 動 & 自動給系補修 & 6 & 3 \\
\hline 幅 & $\sim 280$ & 9 & 4 & 化 & 給系自動サプライ & 3 & 0 \\
\hline & $\sim 340$ & 5 & 5 & & 布の自動切り下し(機上 & 3 & 2 \\
\hline & $\sim 390$ & 1 & 4 & & " $($ 台車) & 2 & 1 \\
\hline$\exists$ & $1 \mathrm{C}$ & 1 & 2 & & QSC & 0 & 4 \\
\hline コ & $2 C$ & 43 & 26 & & 綿一般 & 18 & 14 \\
\hline 糸 & $4 \mathrm{C}$ & 10 & 7 & 主 & シーティング & 7 & 3 \\
\hline 選 & $6 \mathrm{C}$ & 6 & 6 & な & デニム & 5 & 5 \\
\hline 択 & $8 \mathrm{C}$ & 0 & 2 & 織 & ウール & 3 & 5 \\
\hline & クランク (平) & 16 & 6 & 物 & 合織·強撚 & 1 & 3 \\
\hline 開 & 消極力么 & 8 & 4 & & 合織一般 & 13 & 4 \\
\hline 口 & 簀極力么 & 18 & 13 & & 化織 & 4 & $\overline{1}$ \\
\hline 装 & 電子ドビー & 13 & 9 & & タオル & 3 & 5 \\
\hline 置 & 電子ジャカート & 5 & 8 & & インテリア & $\overline{4}$ & $\overline{4}$ \\
\hline & 電子開口 & 0 & 2 & & & & \\
\hline & 多相 & 0 & 1 & & & & \\
\hline
\end{tabular}
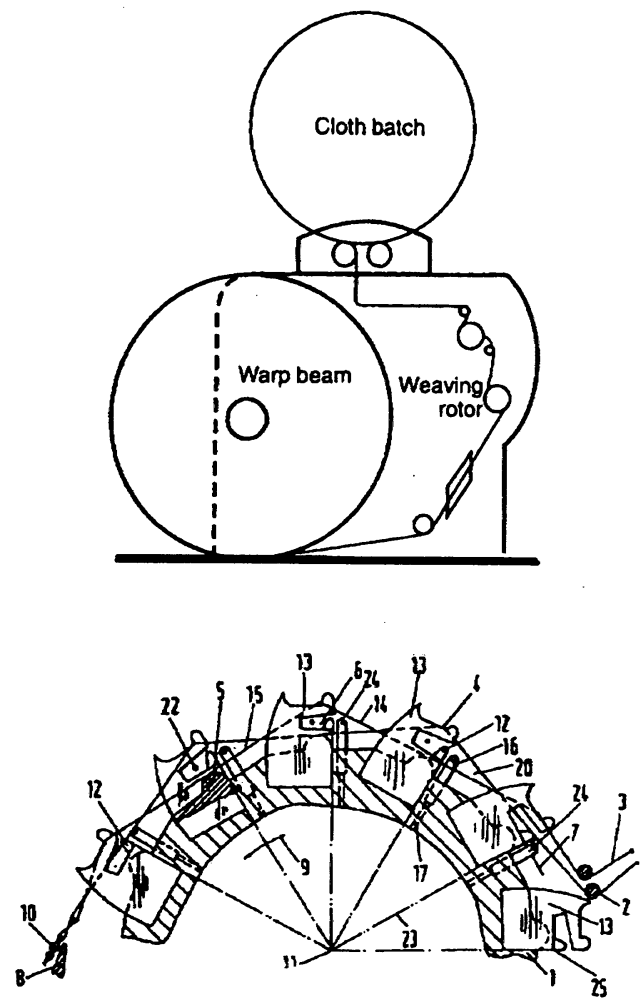

$$
\begin{array}{cll}
3: \text { たて糸 } & 10: \text { 織布 } & 11: \text { ローター } \\
13: \text { 変形おさ } & 16: \text { 補助ノズル } & 22: \text { よこ糸 }
\end{array}
$$

図18 M8300基本原理（Sulzer Ruti 社）

現である.あう1つは高生産性を狙った SOMET 社のたて型 2 面織機 Mach3 である．過去の展示会 であ同様なコンセプト機の出展はあった， 2 面同時 に生産 (今回は $340 \mathrm{~cm}$ 幅で $600 \mathrm{rpm}, 2$ 幅) すること による高生産性のメリットと 2 面上下対向して配置 することによる省スペースを狙ったものである. 


\section{7. エコロジーと今後の開発課題}

各機種とも 1）コストメリットを出す回転数の追 求，2）広幅化による生産性の向上，3）織物の多様 化, 差別化に対する装置の開発，4）生産性, 品質確 保の製織技術向上を含めた汎用性の拡大等の開発に 加速がつくだろう。こうした中で，ますます重要と なるのはエコロジー時代を意識した開発の盛り込み である.

1 つは人間性尊重の上に立って，快適な労働環境 を作り上げることである．生産性を追求する上での 回転数の上昇は, どうしてあ振動, 騒音を大きくす る。それらを低減するための材質からメカに至るま での根源対策を急ぐ必要がある．高速化とともに増 大する風綿の除去や織機自体の色調も重要なアイテ ムである.

あう 1 つは省資源の追求である．ウォータージェ ット織機では排水のリサイクルむ含めて，いかに使 用水量を少なくするか，そしてェアジェット織機で は空気消費量の低減である。更には運動体の軽量化 や短ストロークで動力エネルギーを少なくするこ と，また，産業廃棄物となり得る捨系をゼロにする
ことも課題である.

\section{8.あとがき}

緘維産業は, 人間が生活していく上に必要な「衣」 を担う重要な産業である。ここでは，その一翼を担 う織布 (織機) の発展について述べてきた。 それは 一口で, 生産性向上のそのものの発展, といっても 過言ではない。しかし，今後は「人」や「地球」と いう要素を意識したエコロジー時代らしい織機技術 の開発がメーカーの責務であると考えている.メ一 カーの独自の開発でなく，ユーザーとの協調の上に 立った開発が問われることになろう。

最後に，本文の中には諸先輩の出版物などから資 料や文面を引用させて頂いたことをお断りしてお $<$.

\section{参考文献}

1）機械振興協会経済研究所, わが国瀻維機械の技術発展調査 研究報告書 II

2)「ジェットルーム織布」(日本織維機械学会刊)

3）「ジェットルームハンドブック」(日本織維機械学会刊)

4)「レピアルームハンドブック」(日本紻維機械学会刊)

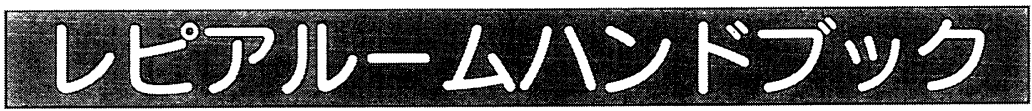

社団法人 日本繊維機械学会 織機研究委員会編

B 5 判，100頁，定価 2,400 円（本体 2,330 円）送料500円

\begin{tabular}{|c|c|c|c|c|c|c|}
\hline 執 筆 者 & 浅井富士雄 & (侏)石川製作所 & 小嶋 & ミヤテック㑣) & 小島 & (梾トーーメンインダックス \\
\hline & 川島進 & 津田駒工業(㑣) & 垣中 & 春日電機(㑣) & 岡崎 & (株平岩鉄工所 \\
\hline & 池畠 & 兼松(株) & 興治 & 新興産業(㑣) & 伊藤志津夫 & (樮)アルス \\
\hline & 山東 敏告 & ピカノール(侏) & 西中野克己 & (有)エムエスディ & & \\
\hline
\end{tabular}

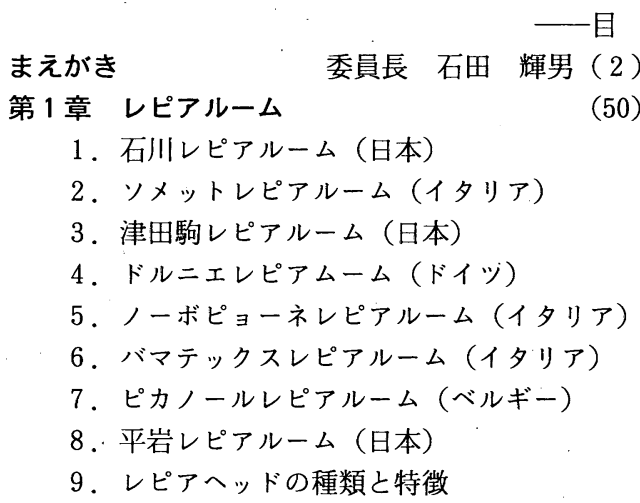

次-
第2章 よこ糸フィーダ
1.ロイよこ糸フィーダ
2. カスガウェフト糸フィーダ
3.よこ糸フィーダ一覧

第3 章 最近のレピアルーム

1. ITMA'95にみるエアジェットルーム vs レピアルーム

2.レピアルームハンドブックにみる技術開発

3.レピアルームによる製織事例

\section{《資料編》}

